\title{
A resource efficient and environmentally safe charge structure for mining in an open-pit
}

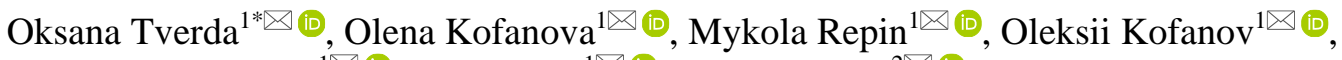

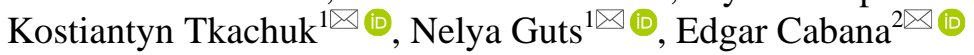

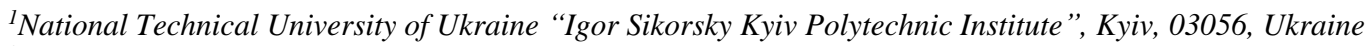 \\ ${ }^{2}$ Universidad Nacional de San Agustin de Arequipa, Arequipa, 4100, Peru \\ *Corresponding author: e-mail tverdaya@ukr.net, tel. +380634900053
}

\begin{abstract}
Purpose. The purpose is to reduce mineral losses during the explosive destruction of rocks and environmental pollution by harmful gases and fine particulate matter.

Methods. To achieve the objectives of the study, methods of physicochemical analysis and mechanics of continuous media have been used. The method of physico-chemical analysis has been used to determine the quantitative and qualitative characteristics of the composition of the well stemming depending on the parameters of the well, the type of explosive, the amount and type of harmful gases formed during the explosion. Methods of solid medium mechanics have bee $n$ used to establish the patterns of pressure waves during an explosion depending on the characteristics of the gap filler between the charge and the well wall. To solve the problem of the behavior of a two-layer medium during the loading of a cylindrical cavity by a nonstationary load, a numerical method based on the finite-difference McCormack predictorcorrector scheme has been used.
\end{abstract}

Findings. A resource-saving and environmentally friendly charge structure for rock mining by explosion was developed. The design of the charge involves the formation of a gap between the charge and the wall of the borehole, and filling it with a suspension of calcium hydroxide or a suspension of calcium carbonate.

Originality. The dependences of the volume of harmful gases $\left(\mathrm{NO}_{2}, \mathrm{CO}_{2}, \mathrm{CO}\right)$ formed during the explosive destruction of rocks and the magnitude of the pressure peak in the area close to the charge on the chemical composition of the filler of the radial gap between the charge and the well wall have been set.

Practical implications. Developed charge design allows to neutralize the harmful gases formed during the explosion, to reduce the pressure peak in the area of the rock massif close to the charge, and can be widely used in non-metallic quarries that extract minerals for the production of crushed stone.

Keywords: environmental pollution, explosion, explosive, charge structure, harmful gases, mineral losses, neutralization of gases

\section{Introduction}

The main anthropogenic factors of environmental pollution include, first of all, large industrial complexes, which are consumers of raw materials, energy, water, air, land and at the same time the most powerful sources of almost all types of pollution (mechanical, chemical, physical, physicochemical, and biochemical at all) [1].

The mining complex, as one of the types of economic activity, is a serious polluter of the environment. Open pit mining leads to pollution of water and air basins, changes, disturbances in the structure and deterioration of the fertile soil layer, to significant landscape disturbances. This, in turn, causes the death or degradation of flora and fauna. Also, large plots of land are engaged in tailings and dumps of rocks [2], [3].
During mining operations, a significant amount of harmful gases enters the air as well as fine particulate matter (PM). Emissions of harmful substances contain both: chemicals, that are part of rocks, and substances, that are released during the explosive destruction of rocks and during the operation of machines and mechanisms used in the technology of crushed stone production. These gases are gases nitrogen oxides, carbon oxides, sulfur compounds etc. The emission of these harmful substances leads to the gradual degradation of plantations, reducing their productivity and losing of stability. Under the influence of "foreign" substances for living organisms, the ultramicroscopic structure of cells of plant organisms is disturbed, the intensity of growth and productive reactions are slowed down, the life expectancy of organisms is reduced, aging processes are accelerated [4].

Received: 10 April 2021. Accepted: 8 November 2021. Available online: 24 December 2021

(C) 2021. O. Tverda et al.

Published by the Dnipro University of Technology on behalf of Mining of Mineral Deposits. ISSN 2415-3443 (Online) | ISSN 2415-3435 (Print)

This is an Open Access article distributed under the terms of the Creative Commons Attribution License (http://creativecommons.org/licenses/by/4.0/),

which permits unrestricted reuse, distribution, and reproduction in any medium, provided the original work is properly cited. 
The scale of dust pollution is evidenced by the fact that the concentration of dust near the sources of it formation can range from 0.5 to $3000 \mathrm{mg} / \mathrm{m}^{3}$ and above (Table 1) [5]. The concentration of harmful gases can exceed the maximum permissible concentration (MPC) by 10 times or more (Table 2) [6]. Mass explosions are the largest source of dust and harmful gas pollution. The efficiency of the following technological processes and the work of the mining enterprise as a whole depends on the results of the explosion.

Table 1. Characteristics of dust sources during the open pit mining [5]

\begin{tabular}{lc}
\hline \multicolumn{1}{c}{ Process } & Dust release, $\mathrm{mg} / \mathrm{m}^{3}$ \\
\hline $\begin{array}{l}\text { Extraction and } \\
\text { loading operations }\end{array}$ & $2.9-100.4$ \\
\hline Boring & $0.5-2422$ \\
\hline Blasting & $400-3100$ \\
\hline Transportation & $0.9-100.4$ \\
\hline Grinding & $0.9-81.6$ \\
\hline Dump formation & $0.8-33.7$ \\
\hline
\end{tabular}

Table 2. Emissions of pollutants during mass explosions [6]

\begin{tabular}{cccc}
\hline $\begin{array}{c}\text { Conta- } \\
\text { minant }\end{array}$ & $\begin{array}{c}\text { Concentration } \\
\text { in the dust and } \\
\text { gas cloud, } \\
\mathrm{mg} / \mathrm{m}^{3}\end{array}$ & $\begin{array}{c}\text { Maximum } \\
\text { allowable } \\
\text { concentration } \\
\text { (maximum } \\
\text { single), } \mathrm{mg} / \mathrm{m}^{3}\end{array}$ & $\begin{array}{c}\text { Annual } \\
\text { emission of } \\
\text { harmful sub- } \\
\text { stances, t/year }\end{array}$ \\
\hline $\begin{array}{c}\text { Suspended } \\
\text { substances }\end{array}$ & 2562.4 & 0.15 & 7715 \\
\hline $\begin{array}{c}\text { Carbon (II) } \\
\text { oxide }\end{array}$ & 564.41 & 5 & 1699.4 \\
\hline $\begin{array}{c}\text { Nitrogen (IV) } \\
\text { oxide }\end{array}$ & 37.4 & 0.2 & 112.58 \\
\hline
\end{tabular}

A special threat to the environment and people is the spread of the dust and gas cloud, in which dust is present in the amount of 0.027 to $0.17 \mathrm{~kg} / \mathrm{m}^{3}$ of rock mass. The total amount of formed carbon (II) oxide reaches from 60 to 93 liters per $1 \mathrm{~kg}$ of explosive, and nitrogen (II) oxide and nitrogen (IV) oxide - from 3.5 to $7 \mathrm{l} / \mathrm{kg}$ [7]. During mass explosions in quarries, up to 100 tons of dust and up to $30000 \mathrm{~m}^{3}$ of $\mathrm{CO}$ (in the case of an explosion up to 600 tons of explosives) enter the atmosphere. In the process of detonation from 600 to 800 tons of explosives at a distance of $1 \mathrm{~km}$ from the quarry, the dust concentration reaches from $1200 \cdot$ to $2800 \cdot \mathrm{MPC}$, and at a distance of $10 \mathrm{~km}-90 \cdot \mathrm{MPC}$ [8]. Dust and gas cloud rises to a height of $800 \mathrm{~m}$, spreads in the direction of the wind and settles on the earth's surface, including in residential areas and on agricultural lands, which creates significant negative effects within a radius of $20 \mathrm{~km}$ from the quarry [9].

Industrial dust destroys equipment, causes occupational diseases, worsens sanitary and hygienic working conditions, and in the process of extraction of minerals by explosive destruction is also an irreversible loss of minerals. Industrial dust is the cause of skin and mucous membrane diseases, non-specific respiratory diseases, allergic diseases, occupational poisoning, cancer, pneumoconiosis. Dust can spread over long distances due to wind currents, fall with precipitation, or create secondary geochemical anomalies. The size of the dust particles (the degree of dispersion of dust) is of great importance, because the smaller the dust particles are, the longer they remain in the air in a suspended state. The most dangerous particles are from 2 to 5 microns in size, because they penetrate deeper into the airways and, reaching the alveoli, settle in them.
Modern open pit mining technologies are based on using the well charge method and, as a consequence, using the high-energy explosives causes a significant regrinding of natural raw materials in the immediate area of the contact "explosive-rock", which leads to the loss of nonrenewable resources. Thus, blasting has negative effects in terms of environmental safety, human health and resource conservation. Obtaining the rock mass of the required fractional composition is ensured by the technological parameters of the blasting operations and the design of the explosive charge, the improvement of which will reduce the pressure on the environment and allow to minimize technological losses of raw materials. This will ultimately help to improve the technical and economic performance of mining enterprises. It should be noted that the significant environmental impact of this industry will also be significantly reduced.

The analysis of theoretical and experimental studies on increasing the environmental safety of blasting on rock quarries allowed us to establish: that the influence of various natural and technological factors on the explosion process and its ecological consequences has been studied in great detail; a large number of different charge structures, that help to regulate the environmental impact and the level of resource conservation have been developed; methods and recommendations for calculating the parameters of mass explosions have been developed; new high-performance and safe explosives, charge initiation devices with non-electrical initiation systems have been implemented; a considerable number of methods of dust suppression and neutralization of harmful gases have been developed [6], [10]-[24].

However, despite the achieved results in improving the environmental safety of blasting on quarries, the problem of greening the technological processes that accompany them requires further solution. The developed charge structures (Table 3) have not been widely used. The main reasons are complexity and cost. Rock quarries still have a problem with the high percentage of substandard rock mass fractions in the fractional composition. In particular, over-crushed, which, unlike fractions larger than condition, cannot be reduced to conditioned size. It is the over-crushed fraction that is the source of dust formation and occupies the major share of mining waste.

An attempt has been made in [25] to solve this problem. The authors have been established the regularity of the passage of pressure waves during the explosion, depending on the acoustic stiffness of the filler of gap between the charge and the wall of the borehole and its magnitude. It is determined that with increasing of the filler acoustic rigidity, the pressure peak in the near-charge zone decreases by 15-20\%. During limestone blasting, the pressure peak, when water is used as a filler of the gap between the charge and the walls of the well, is $1 \cdot 10^{7} \mathrm{~Pa}$. At the same time the pressure peak, when iron (III) sulfate aqueous solution is used as a filler of the gap between the charge and the walls of the borehole, is $8 \cdot 10^{6} \mathrm{~Pa}$, which is $20 \%$ less. It is established that solutions with higher acoustic stiffness will allow to reduce the volume of dust formation and increase the homogeneity of the fractional composition of the rock mass. This is realized by reducing the amplitude of the pressure waves at the boundary of the medium distribution by $20 \%$ and more and increasing the amplitude width by $25-30 \%$. 
Table 3. Dust and gas reducing and resource conservation measures during an explosion

\begin{tabular}{|c|c|c|}
\hline Group of measures & An action, measure or method of dust reducing and resource conservation during an explosion & Link \\
\hline \multirow{10}{*}{$\begin{array}{l}\text { Technological } \\
\text { measures }\end{array}$} & Blasting of high ledges & [6] \\
\hline & Reducing the diameter of the charge & [10] \\
\hline & Blasting on uncleaned rock mass & [6] \\
\hline & Separation of charge column by air and inert gaps & [10] \\
\hline & Reducing the magnitude of the borehole breakaway & [10] \\
\hline & Expanding the well network and reducing the proportion of explosives & [11] \\
\hline & Using of combined charges with multi-directional initiation and diagonal switching schemes of blasting network & [12] \\
\hline & Formation of an air cavity at the bottom of the borehole & [13] \\
\hline & Formation of air or water gaps between the charge and the wall of the borehole & [14], [15] \\
\hline & $\begin{array}{l}\text { Changing of technological parameters, in particular the site width, the bench height and length of the } \\
\text { excavating unit which might provide the necessary intensity of mining operations in the deep levels in an } \\
\text { open-cast mine }\end{array}$ & [16] \\
\hline \multirow{7}{*}{$\begin{array}{l}\text { Engineering and } \\
\text { technical measures }\end{array}$} & Use of more environmentally friendly explosives or change their recipe & [17], [18] \\
\hline & $\begin{array}{l}\text { Application of hydro stemming or stemming containing surfactants or stemming containing substances } \\
\text { that can neutralize harmful gases }\end{array}$ & $\begin{array}{c}6] \\
{[19]-[21]}\end{array}$ \\
\hline & Spraying of blocks before a blast & {$[6]$} \\
\hline & Irrigation of the blown up block & [6] \\
\hline & Constructing the hydro curtains & [6] \\
\hline & $\begin{array}{l}\text { Using special decks in boreholes to enhance the quality of fractional composition of rock mass and to } \\
\text { reduce the level of vibration }\end{array}$ & [22] \\
\hline & $\begin{array}{l}\text { Research of physical and mechanical properties of rocks and the use of the obtained data in the process } \\
\text { of designing the blasting parameters and charge formation }\end{array}$ & [23] \\
\hline $\begin{array}{l}\text { Organizational } \\
\text { measures }\end{array}$ & $\begin{array}{l}\text { Carrying out mass explosions over a period of maximum wind activity with respect to the wind rose for a } \\
\text { specific region }\end{array}$ & [24] \\
\hline
\end{tabular}

The disadvantage of this approach is the choice of a solution of iron (III) sulfate as a solution to fill the gap between the charge and the wall of the borehole, as the explosion of the borehole charge produces gaseous sulfur dioxide, and this will require additional funds to neutralize it. An alternative, for example, is a completely harmless aqueous solution of sodium chloride $\mathrm{NaCl}$, but its maximum density can reach only $1200 \mathrm{~kg} / \mathrm{m}^{3}$, which is much less than the maximum density of an aqueous solution of iron (III) sulfate. This situation encourages the improvement of the developed charge design in order to reduce the loss of minerals and the release of dusty fractions.

The purpose of the paper is to reduce mineral losses during the explosive destruction of rocks and environmental pollution by harmful gases and fine particulate matter. To achieve the purpose, the following tasks have been set:

- to analyze the current achievements in minimizing the impact of explosive destruction of rocks on the environment and in increasing the level of resource conservation during the mining in open-pits;

- to develop measures to reduce the impact of blasting operations during the extraction of non-metallic minerals on the environment and to increase the level of resource conservation.

\section{Theory}

During the process of explosive destruction of rocks, several zones are formed. The zone closest to the epicenter is called the re-crushing zone and is a source of dust and re-crushed fractions of rock mass during the explosion. The shredded fraction of rock mass is an irreversible loss of minerals.

According to the analysis of the literature, this problem can be positively solved with the help of special technology for charging wells and detonating charges of explosives, which are formed in flexible shells (polyethylene sleeves). This technology is implemented using a system of feeding sleeves with laying and braking [26].
At the quarry, the sleeve is laid in the sleeve feeder. Sleeve feeders are transported to the charging block and installed in boreholes (Fig. 1). The explosive is fed manually from bags or mechanized by any charger through the funnel of the sleeve feeder into the sleeve. The sleeve under the weight of the explosive enters the borehole [27].

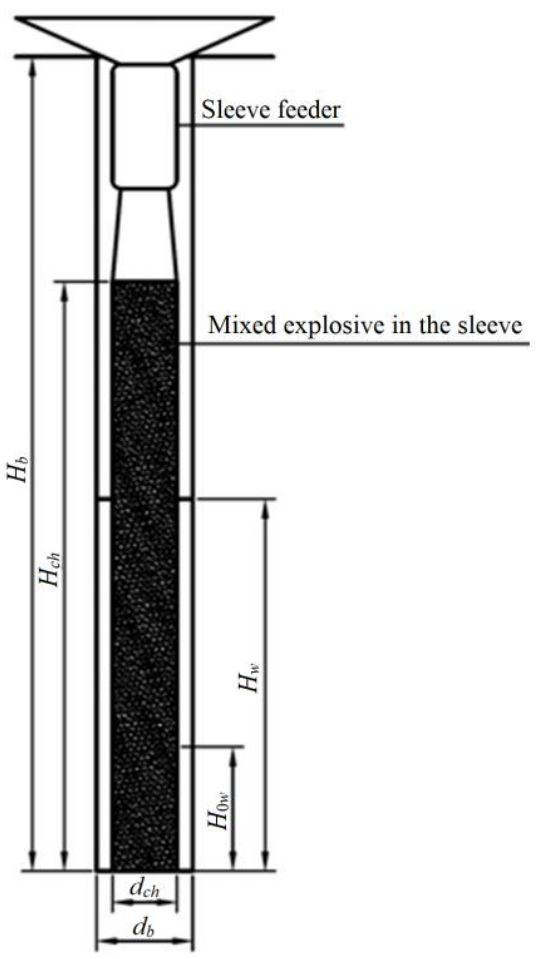

Figure 1. Scheme of explosive charge generated in the borehole using the sleeve feeder: $d_{b}$ - borehole diameter; $d_{c h}-$ charge diameter; $\mathrm{H}_{0 w}$ - maximum initial water level in the borehole; $\mathrm{H}_{w}$ - water level after feeding the sleeve; $H_{c h}$-charge length; $H_{b}$ - the length of the borehole [27] 
The technology of charging flooded boreholes (or dry) with the formation of charges in polyethylene sleeves includes the following basic operations:

- mechanized laying of a sleeve;

- installation of lower fighters in boreholes;

- installation of sleeve feeders in the wellhead of boreholes;

- mechanized (or manual) filling of the explosive into the sleeve with its simultaneous supply, which is slowed down during the process of lowering into the borehole, fixing the upper end in the wellhead;

- laying the charge for at least 0.5 hours (depending on the degree of waterlogging of the borehole);

- installation of the top fighter in a sleeve through a funnel and pouring of explosive to design level;

- extraction of the sleeve feeder from the borehole.

In the case of charging fully flooded boreholes, the sleeve feeder is installed on a specially made stand ("tripod"), which ensures the placement of this device from the wellhead at a height of $0.1-0.2 \mathrm{~m}$.

The length of the polyethylene sleeve during charging flooded boreholes must ensure the placement of the calculated mass of the explosive in it and have a reserve for accidental twisting, subsidence, etc. Therefore, for each specific condition, the length of the sleeve is set by measuring the depth of the borehole.

The application of this technology provides [15]:

- full or partial replacement of expensive explosives;

- uniformity of rock mass crushing due to increase of efficiency of explosion caused by more stable power and detonation characteristics of explosives, and also existence of a gap between a charge and a borehole wall;

- reducing the yield of large and re-crushed fractions in the collapse of the rock mass;

- mechanization of loading of explosives in sleeves and stemming of boreholes that practically excludes use of manual work;

- increasing technical, economic and environmental efficiency of mass explosions.

During charging boreholes with explosives in the sleeves there is a water gap between the sleeve and the rock. The compressibility of water is greater than the compressibility of rocks, so water is a cushioning buffer between the products of detonation and rock, resulting in the amount of local destruction (re-crushing) is reduced. The water gap works as a damper. It reduces the value of the maximum pressure in the near zone during the explosion, which in turn leads to reduction of the re-grinding zone (Fig. 2) and hence the volume of dust in general [27].

To enhance the described effect, it is proposed to use suspensions of calcium hydroxide and calcium carbonate instead of water as filler for the gap between the charge and the borehole wall. The use of such suspensions, in addition to reducing the peak in the area close to the charge, will also neutralize harmful gases (for example, $\mathrm{CO}_{2}, \mathrm{NO}_{2}$ and $\mathrm{CO}$ ) formed during the explosion.

So, neutralization of harmful gases under the condition of using as filler for the gap between the charge and the borehole wall a suspension of calcium hydroxide will take place in accordance with the chemical reaction Equations:

$2 \mathrm{Ca}(\mathrm{OH})_{2}+4 \mathrm{NO}_{2}=\mathrm{Ca}\left(\mathrm{NO}_{2}\right)_{2}+\mathrm{Ca}\left(\mathrm{NO}_{3}\right)_{2}+2 \mathrm{H}_{2} \mathrm{O}$

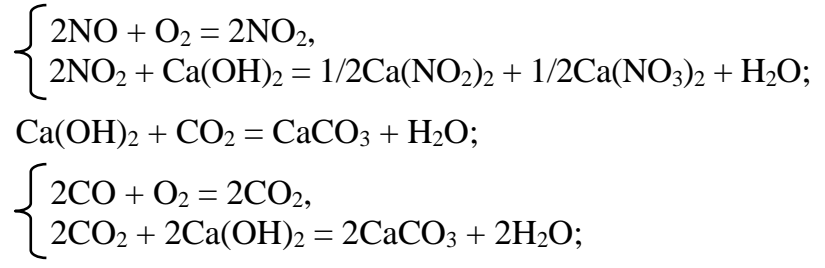

$\mathrm{Ca}(\mathrm{OH})_{2}+\mathrm{CO}=\mathrm{CaCO}_{3}+\mathrm{H}_{2}$ (at a temperature of about $400^{\circ} \mathrm{C}$ ).

(a)

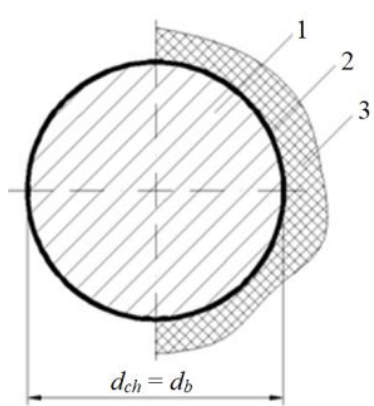

Figure 2. The re-grinding zone formed by blasting a continuous charge (a) and a charge with an annular gap (b): 1 - explosive charge; 2 -borehole wall; 3 -re-grinding zone

Neutralization of harmful gases under the condition of using as filler for the gap between the charge and the borehole wall a suspension of calcium carbonate will take place in accordance with the chemical reaction Equations:

$4 \mathrm{NO}_{2}+2 \mathrm{CaCO}_{3}=\mathrm{Ca}\left(\mathrm{NO}_{3}\right)_{2}+\mathrm{Ca}\left(\mathrm{NO}_{2}\right)_{2}+2 \mathrm{CO}_{2} ;$

$\left\{\begin{array}{l}2 \mathrm{NO}+\mathrm{O}_{2}=2 \mathrm{NO}_{2}, \\ 2 \mathrm{NO}_{2}+\mathrm{CaCO}_{3}+1 / 2 \mathrm{O}_{2}=\mathrm{Ca}\left(\mathrm{NO}_{3}\right)_{2}+\mathrm{CO}_{2} ;\end{array}\right.$

$\mathrm{CaCO}_{3}+\mathrm{CO}_{2}=\mathrm{Ca}\left(\mathrm{HCO}_{3}\right)_{2}$.

At a temperature of $900-1200^{\circ} \mathrm{C}$, calcium carbonate decomposes: $\mathrm{CaCO}_{3} \rightarrow \mathrm{CaO}+\mathrm{CO}_{2}$ which has a positive effect on the absorption of harmful gases. The resulting $\mathrm{CaO}$ will also react with carbon and nitrogen dioxides and again will form calcium carbonate $\mathrm{CaCO}_{3}$, calcium nitrate $\mathrm{Ca}\left(\mathrm{NO}_{3}\right)_{2}$ and calcium nitrite $\mathrm{Ca}\left(\mathrm{NO}_{2}\right)_{2}$ respectively.

The use of slaked lime suspension will allow providing the effect of irrigation of the dust and gas cloud, which, in turn, will reduce the concentration of dust in the air even in the case of decomposition of calcium hydroxide with the subsequent interaction of the reaction product - calcium oxide with carbon dioxide and/or with nitrogen dioxide according to the reaction Equations:

$$
\left\{\begin{array}{l}
\mathrm{Ca}(\mathrm{OH})_{2} \rightarrow \mathrm{CaO}+\mathrm{H}_{2} \mathrm{O}, \\
\mathrm{CaO}+\mathrm{CO}_{2}=\mathrm{CaCO}_{3}, \\
2 \mathrm{CaO}+4 \mathrm{NO}_{2}=\mathrm{Ca}\left(\mathrm{NO}_{2}\right)_{2}+\mathrm{Ca}\left(\mathrm{NO}_{3}\right)_{2} .
\end{array}\right.
$$

It is proposed to calculate the pressure peaks in the zone close to the charge during the explosion (for each filler of the gap between the charge and the borehole wall) on the basis of an adapted model of G. Lyakhov [25].

\section{Results and discussion}

The calculation of the effectiveness of using the suspensions of the considered substances as fillers of the gap between the charge and the borehole wall was carried out under the condition that diameter of the borehole is $250 \mathrm{~mm}$, the 
diameter of the charge $-160 \mathrm{~mm}$, the length of the borehole $16 \mathrm{~m}$, the length of the charge $-12 \mathrm{~m}$, the length of the stemming $-4 \mathrm{~m}$. Water, calcium hydroxide suspension and calcium carbonate suspension were considered as fillers. Both suspensions consist of $70 \%$ water and $30 \%$ dry matter (calcium hydroxide suspension andcalcium carbonate suspension). Explosive - Hranemit. The amount of gases from 1 borehole is, $\mathrm{dm}^{3}: \mathrm{NO}_{2}-60.9 ; \mathrm{CO}-7830 ; \mathrm{CO}_{2}-22620 ; \mathrm{N}_{2}-$ 62350 . The density of the rock is $2650 \mathrm{~kg} / \mathrm{m}^{3}$, the speed of sound in the rock is $4500 \mathrm{~m} / \mathrm{s}$. The results of the calculation are given in Table 4.

As can be seen from the Table 4, the use of calcium hydroxide suspension and calcium carbonate suspension allows to completely neutralize harmful gases formed during the explosion. According to the results of the calculation, the amount of active substance could even be reduced, but it should be noted that its excess is necessary to create suspensions with characteristics that would reduce the pressure peak in the near-charge zone of the rock. Note that both calcium hydroxide and calcium carbonate are, respectively, slightly and poorly soluble substances, which greatly facilitates the technological processes for preparing their suspensions. In particular, according to the values of the solubility products of these substances $\left(\mathrm{SP}\left(\mathrm{Ca}(\mathrm{OH})_{2}\right)=\left[\mathrm{Ca}^{2+}\right] \cdot\left[\mathrm{OH}^{2-}\right]=5.510^{-6}\right.$, and $\mathrm{SP}\left(\mathrm{CaCO}_{3}\right)=\left[\mathrm{Ca}^{2+}\right] \cdot\left[\mathrm{CO}_{3}{ }^{2-}\right]=4.810^{-9}$ in a temperature range close to standard conditions [28]), calcium carbonate is less water-soluble than calcium hydroxide. At the same time, it is known that poorly soluble salts practically do not undergo hydrolysis, although it is impossible to completely deny the possibility of hydrolytic processes, in particular, calcium carbonate, occurring in an aqueous medium. That is, almost partial hydrolysis of calcium carbonate can proceed only through the first stage according to the reaction Equations, and salt hydrolysis through the second stage, most likely, will not take place:

$$
\begin{aligned}
& \mathrm{CaCO}_{3} \leftrightarrow \mathrm{Ca}^{2+}+\mathrm{CO}_{3}{ }^{2-} . \\
& \text { I stage: } \mathrm{CO}_{3}{ }^{2-}+\mathrm{H}-\mathrm{OH} \rightleftarrows \mathrm{HCO}_{3}^{-}+\mathrm{OH}^{-} \\
& \text {II stage: } \mathrm{HCO}_{3}{ }^{-}+\mathrm{H}-\mathrm{OH} \leftrightarrow \mathrm{H}_{2} \mathrm{CO}_{3}+\mathrm{OH}^{-}
\end{aligned}
$$

\begin{tabular}{|c|c|c|c|c|c|c|c|c|}
\hline $\begin{array}{c}\text { Filler } \\
\text { of the gap }\end{array}$ & $\begin{array}{l}\text { The density } \\
\text { of the filler, } \\
\qquad \mathrm{kg} / \mathrm{m}^{3}\end{array}$ & $\begin{array}{c}\text { The speed } \\
\text { of sound in } \\
\text { the filler, } \\
\mathrm{m} / \mathrm{s}\end{array}$ & $\begin{array}{l}\text { The mass of water } \\
\text { in the gap between } \\
\text { the charge and the } \\
\text { borehole wall at a given } \\
\text { suspension density, kg }\end{array}$ & $\begin{array}{l}\text { The mass of active } \\
\text { substance in the gap } \\
\text { between the charge and } \\
\text { the borehole wall at a } \\
\text { given suspension } \\
\text { density, kg }\end{array}$ & $\begin{array}{l}\text { The vol } \\
\text { chemis } \\
1 \mathrm{~kg} \text { of }\end{array}$ & $\begin{array}{l}\text { ne of gas } \\
\text { ption by } \\
\text { he filler, } \\
3\end{array}$ & $\begin{array}{l}\text { The required } \\
\text { mass of active } \\
\text { substance for } \\
\text { one borehole, } \\
\text { kg }\end{array}$ & $\begin{array}{l}\text { Peak pressure } \\
\text { acting on the } \\
\text { inner surface } \\
\text { of the well, } \mathrm{Pa}\end{array}$ \\
\hline \multirow{3}{*}{$\begin{array}{l}\text { Without } \\
\text { filler }\end{array}$} & \multirow{3}{*}{-} & \multirow{3}{*}{-} & \multirow{3}{*}{-} & \multirow[t]{3}{*}{ (a) } & $\mathrm{NO}_{2}$ & - & \multirow{3}{*}{-} & \multirow{3}{*}{9.66} \\
\hline & & & & & $\mathrm{CO}_{2}$ & - & & \\
\hline & & & & & $\mathrm{CO}$ & - & & \\
\hline \multirow{3}{*}{ Water } & \multirow{3}{*}{1000} & \multirow{3}{*}{1450} & \multirow{3}{*}{348} & \multirow{3}{*}{-} & $\mathrm{NO}_{2}$ & - & \multirow{3}{*}{-} & \multirow{3}{*}{8.28} \\
\hline & & & & & $\mathrm{CO}_{2}$ & - & & \\
\hline & & & & & $\mathrm{CO}$ & - & & \\
\hline \multirow{3}{*}{$\begin{array}{c}\text { Calcium } \\
\text { hydroxide } \\
\text { suspension }\end{array}$} & \multirow{3}{*}{1363} & \multirow{3}{*}{2150} & \multirow{3}{*}{332} & \multirow{3}{*}{143} & $\mathrm{NO}_{2}$ & 0.45 & \multirow{3}{*}{113} & \multirow{3}{*}{7.44} \\
\hline & & & & & $\mathrm{CO}_{2}$ & 0.3 & & \\
\hline & & & & & $\mathrm{CO}$ & 0.212 & & \\
\hline \multirow{3}{*}{$\begin{array}{c}\text { Calcium } \\
\text { carbonate } \\
\text { suspension }\end{array}$} & \multirow{3}{*}{1513} & \multirow{3}{*}{2800} & \multirow{3}{*}{369} & \multirow{3}{*}{158} & $\mathrm{NO}_{2}$ & 0.443 & \multirow{3}{*}{50} & \multirow{3}{*}{7.06} \\
\hline & & & & & $\mathrm{CO}_{2}$ & - & & \\
\hline & & & & & $\mathrm{CO}$ & 0.157 & & \\
\hline
\end{tabular}

Table 4. The results of calculating the efficiency of fillers of the gap between the charge and the borehole wall

*The degree of conversion for $\mathrm{NO}_{2}$ and $\mathrm{CO}_{2}$ is 0.99 , and for $\mathrm{CO}-0.7$

As can be seen from the presented reaction Equations, due to the formation of excessive amounts of hydroxyl ions $\mathrm{OH}^{-}$during potentially possible hydrolytic processes, the acidity of the medium in the gap between the charge and the borehole wall $(\mathrm{pH})$ will shift towards the alkaline medium $(\mathrm{pH}>7)$, which is a positive phenomenon for the considered technological process. This means that even in the case of partial hydrolysis of calcium carbonate and an increase in the concentration of hydroxyl ions $\mathrm{OH}^{-}$as a result, the chemisorption of harmful components of the explosion will be carried out according to the previously presented mechanism, represented by Equations (1)-(4).

The calculation of peaks pressure acting on the inner surface of the borehole has been performed on the basis of G.M. Lyakhov's mathematical model for the above conditions. The results of the calculation are presented in the Figure 3.

As can be seen from the figures, the use of suspensions of $\mathrm{Ca}(\mathrm{OH})_{2}$ and $\mathrm{CaCO}_{3}$ as fillers of the gap between the charge and the wall of the borehole allows, in addition to neutralization of harmful gases, formed during the explosion, to reduce pressure peaks in the area close to the charge. This zone is a source of crushed (substandard) fraction, which is an irre- versible loss of minerals. With the use of calcium carbonate suspension, the pressure peak can be reduced by almost $15 \%$, which will significantly reduce the volume of the crushed fraction, including dust, which also affects the environment and health of quarry workers and residents.

\section{Conclusions}

The design of the charge, which involves the formation of a gap between the charge and the wall of the borehole, and filling it with a suspension of calcium hydroxide or a suspension of calcium carbonate, has been developed. This charge design differs from the known ones in that it allows not only to reduce the pressure peak in the area of the rock massif close to the charge, but also to neutralize the harmful gases formed during the explosion. If a suspension of calcium hydroxide is used as a filler, it is possible to neutralize all harmful gases formed during the explosion, provided that a suspension of calcium carbonate is used - all except carbon dioxide. During using explosives containing sulfur, as well as in the case of blasting rocks containing it, the utilization of sulfur compounds, in particular $\mathrm{SO}_{2}$ and $\mathrm{H}_{2} \mathrm{~S}$, will be achieved by similar mechanisms. 
(a)

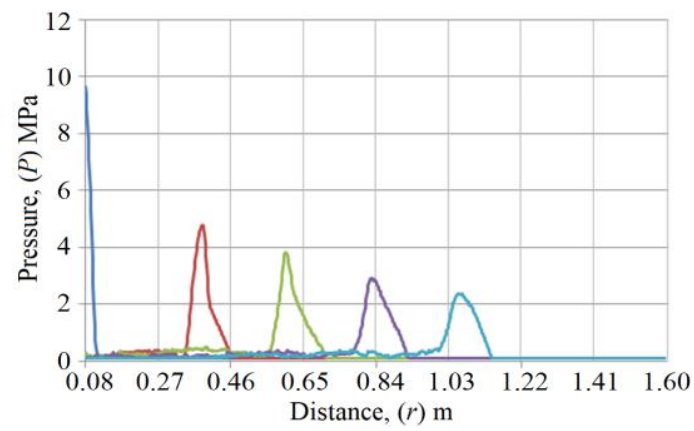

(b)

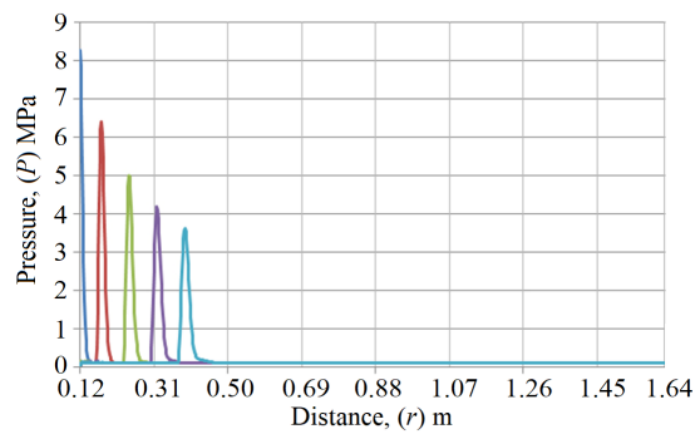

(c)

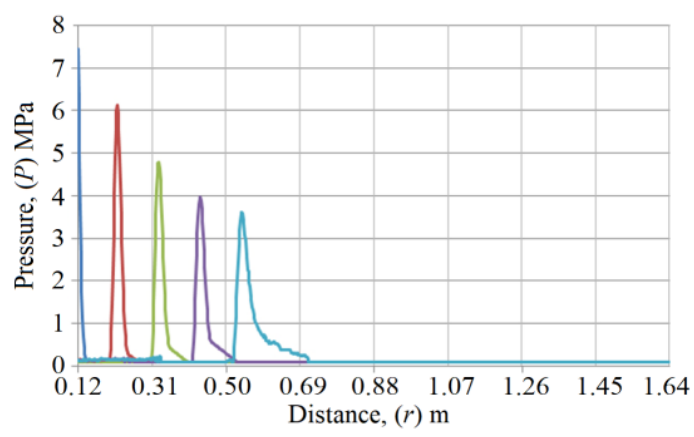

(d)

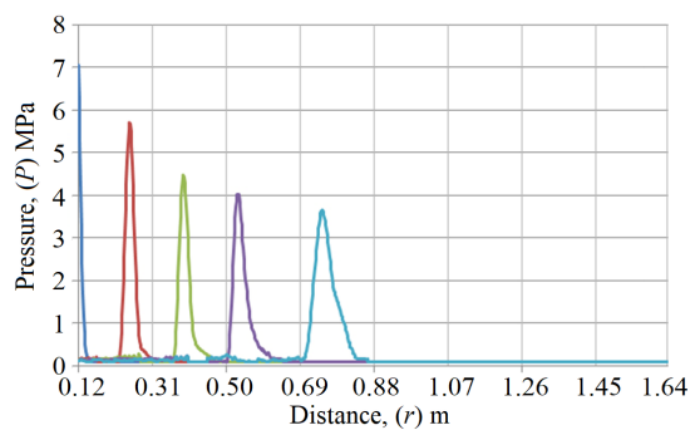

Figure 3. Dependence of pressure waves propagation on a change in the spatial coordinate for different types of the gap filler between the charge and the walls of the borehole: (a) without filler; (b) water; (c) calcium hydroxide suspension; (d) calcium carbonate suspension

Under the condition that diameter of the borehole is $250 \mathrm{~mm}$, the diameter of the charge $-160 \mathrm{~mm}$, the length of the borehole $-16 \mathrm{~m}$, the length of the charge $-12 \mathrm{~m}$, the length of the stemming $-4 \mathrm{~m}$, calcium hydroxide suspension and calcium carbonate suspension consist of $70 \%$ water and $30 \%$ dry matter, explosive - Hranemit, the density of the rock is $2650 \mathrm{~kg} / \mathrm{m}^{3}$, the speed of sound in the rock is $4500 \mathrm{~m} / \mathrm{s}$, the required amount of calcium hydroxide in each borehole for complete neutralization of harmful gases is $113 \mathrm{~kg}$, and calcium carbonate for complete neutralization of harmful gases except carbon dioxide $-50 \mathrm{~kg}$.

In order to reduce the pressure peak in the near-charge zone, the mass of calcium hydroxide and calcium carbonate must be increased in each borehole to 143 and $158 \mathrm{~kg}$, respectively. This mass of active substance will provide the characteristics of the suspension (density and speed of sound), which reduce the pressure peak by $10-15 \%$ compared to the use as a filler of the gap between the charge and the wall of the borehole water.

\section{Acknowledgements}

The authors express their gratitude to the management of the private joint-stock company Tovkachivsky Mining and Processing Plant, in particular to the Chairman of the Board, Volodymyr Savchuk, for facilitating scientific research, providing necessary information and advisory support.

\section{References}

[1] Stegney, Zh., \& Romenskaya, A. (2011). Influence some anthropogenic impact on the environment. Scientific Messenger of Lviv National University of Veterinary Medicine and Biotechnologies named after S.Z. Gzhytskyj, 13(4(50)), 337-340.

[2] Hinzula, M. (2011). Evaluation of sources of pollution of air basin of the enterprise "Burdyakyvskyy special quarry". The Scientific Issues of Ternopil Volodymyr Hnatiuk National Pedagogical University. Series: Geography, (2), 196-201.

[3] Tverda, O., Tkachuk, K., \& Davydenko, Y. (2016). Comparative analysis of methods to minimize dust from granite mine dumps. Eastern-European Journal of Enterprise Technologies, 2(10(80)), 40-46. https://doi.org/10.15587/1729-4061.2016.64840

[4] Gendler, S., \& Kuznetsov, V. (2006). Spatial distribution of environmental risk during the operation of iron ore quarries. Mining Informational and Analytical Bulletin (Scientific and Technical Journal), (1), 196-200.

[5] Serbinova, L., \& Vodianyk, A. (2011). Assessment of dust pollution in the work area and areas adjacent to the granite quarries. Herald of the National Technical University of Ukraine "Kyiv Polytechnic Institute". Series of "Mining”, (20), 189-197. https://doi.org/10.20535/20795688.2011.20.54275

[6] Zvyagintseva, A., \& Zavyalova, A. (2015). Analysis of the basic technological and engineering measures aimed at reducing dust and gas emissions mass explosion at the quarry mining and processing plant. Heliogeophysical Research.

[7] Nikolaev, A. (2015). Installation for airing not deep pits and clean issued by the air of dust. Mining Informational and Analytical Bulletin (Scientific and Technical Journal), (2), 250-254.

[8] Savotchenko, O., \& Zberovskyi, O. (2017). Research of parameters of dust and gas emissions during blasting operations in quarries. Collection of Research Papers of the National Mining University, (51), 218-226.

[9] Zberovskyi, O. (1997). Protection of the atmosphere in the "quarryenvironment-human” ecosystem. Dnipropetrovsk, Ukraine: AP DKT.

[10] Shvydko, P., Melnyk, H., Bykov, E., Dukhin, I., Gafiulov, V., Kononchuk, V., \& Ustymenko, K. (2007). On the issue of reducing the yield of fine fractions during explosion, as well as drilling, explosive consumption and seismic effect during open pit mining. Scientific Journal "Transactions of Kremenchuk Mykhailo Ostrohradskyi National University”, 5(46(1)), 94-97.

[11] Efremov, E., Nikiforova, V., \& Chebenko, Yu. (2012). Influence of the blasthole diameter on explosive area contact with blasting breakage rock and output of fines fractions. The collection " $U p$-to-date resourceand energy- saving technologies in mining industry", 2(10), 9-15.

[12] Humenyk, I., Soboliev, V., Strilets, O., \& Chebenko, V. (2010). Selection and substantiation of downhole charge parameters depending on the intensity of rock crushing by explosion. The collection "Up-to-date resource- and energy- saving technologies in mining industry”, 2(6), 9-16.

[13] Nifadiev, V., Kovalenko, V., Raiymkulov, M., Komissarov, P., \& Basakina, S. (2017). On air-deck borehole charge mechanism. Herald of KRSU, 17(12), 170-174. 
[14] Larichev, L.Yu. (2014). To the question influence of construction charge on process of formation dust clouds at production of blusting works on quarry. Mining Informational and Analytical Bulletin (Scientific and Technical Journal), (12), 352-357.

[15] Prokopenko, V. (2010). Destruction of rocks by borehole charges of explosives in sleeves. Kyiv, Ukraine: NTUU "KPI".

[16] Temchenko, A. (2014). Study of the open-cast mining technology parameters influence on the efficiency of iron-ore deposits development. Naukovyi Visnyk Natsionalnoho Hirnychoho Universytetu, (1), 16-21.

[17] Morera de la Vall González, G. (2018). Dust production in mining. Suppression measures in quarry blasting. Madrid, Spain: The Technical University of Madrid (UPM).

[18] Tverda, O., \& Plyatsuk, L. (2018). The design of borehole plug with a two-stage absorbing system for harmful gases. The collection "Up-todate resource- and energy- saving technologies in mining industry", 1(21), 103-115. https://doi.org/10.30929/2074-1537.2018.1.103-115

[19] Tverda, O., \& Tkachuk, K. (2020). Increasing the level of environmental safety during explosive destruction of rocks in quarries. Technical Engineering, 1(85), 235-241. https://doi.org/10.26642/ten-2020-1(85)235-241

[20] Tverda, O., \& Vorobiov, V. (2012). Justification of the selection criterion of a safe and effective type of explosive during mass explosions in open pits. Collection of Scientific Works "Occupational Health and Safety Issues in Ukraine”, (22), 56-64.

[21] Tverda, O., Kofanova, O., Kofanov, O., Tkachuk, K., Polukarov, O., \& Pobigaylo, V. (2021). Gas-neutralizing and dust-suppressing stemming of borehole charges for increasing the environmental safety of explo- sion. Latvian Journal of Physics and Technical Sciences, 58(4), 15-27. https://doi.org/10.2478/lpts-2021-0030

[22] Balamadeswaran, P., Mishra, A., Sen, P., \& Ramesh, S. (2018). Investigations into the influence of decking on rock fragmentation and ground vibrations by blasting in shallow benches of limestone quarries - a case study. Journal of Mines, Metals and Fuels, 66(1), 39-47.

[23] Korobiichuk, I., Korobiichuk, V., Hájek, P., Kokeš, P., Juś, A., \& Szewczyk, R. (2018). Investigation of Leznikovskiy granite by ultrasonic methods. Archives of Mining Sciences, 63(1), 75-82. https://doi.org/10.24425/118886

[24] Kozlovskaja, T., \& Chebenko, V. (2010). Ways of decline of y-level of ecological danger in districts mining by the opened method. Scientific Journal "Transactions of Kremenchuk Mykhailo Ostrohradskyi National University”, 6(65(1)), 163-168.

[25] Tverda, O., Plyatsuk, L., Repin, M., \& Tkachuk, K. (2018). Controlling the process of explosive destruction of rocks in order to minimize dust formation and improve quality of rock mass. Eastern-European Journal of Enterprise Technologies, 3(10(93)), 35-42. https://doi.org/10.15587/1729-4061.2018.133743

[26] Yefremov, E., Nikiforova, V., \& Nikolenko, Ye. (2008). Influence of the charge design and the level of water cut of rocks on the intensity of their crushing. The Collection "Up-to-date resource- and energy- saving technologies in mining industry”, 2(2), 7-13.

[27] Prokopenko, V., \& Lotaus, K. (2006). Explosion of rocks by borehole charges of explosives in sleeves. Kyiv, Ukraine: NTUU "KPI".

[28] Holbraich, Z. (1986). Workshop on inorganic chemistry. Moscow, Russian Federation: High School.

\section{Ресурсоефективна та екологічно безпечна конструкція заряду для відкритих гірничих робіт}

\section{О. Тверда, О. Кофанова, М. Репін, О. Кофанов, К. Ткачук, Н. Гуц, Е. Кабана}

Мета. Метою дослідження є зменшення втрат корисних копалин та забруднення навколишнього середовища шкідливими газами і пилом під час вибухового руйнування гірських порід на нерудних кар'єрах.

Методика. Для досягнення цілей дослідження застосовувались методи фізико-хімічного аналізу та механіки суцільних середовищ. Метод фізико-хімічного аналізу застосовувався для визначення кількісних та якісних характеристик складу забійки свердловини залежно від параметрів свердловини, типу вибухової речовини, кількості й типу шкідливих газів, утворюваних нею під час вибуху. Методи механіки суцільних середовищ використовувались для встановлення закономірностей проходження хвиль тиску під час вибуху залежно від характеристик заповнювача проміжку між зарядом і стінкою свердловини. Для вирішення задачі про поведінку двошарового середовища в процесі навантаження циліндричної порожнини нестаціонарним навантаженням використовувався числовий метод на основі скінченно-різницевої схеми предиктор-коректор Мак-Кормака.

Результати. Розроблено ресурсозберігаючу та екологічно безпечну конструкцію вибухового заряду, яка передбачає утворення проміжку між зарядом і стінкою свердловини й заповнення його суспензією гідроксиду кальцію або суспензією карбонату кальцію.

Наукова новизна. Встановлено залежності обсягу шкідливих газів $\left(\mathrm{NO}_{2}, \mathrm{CO}_{2}, \mathrm{CO}\right)$, що утворюються під час вибухового руйнування гірських порід, та величини піку тиску у ближній до заряду зоні від хімічного складу заповнювача радіального проміжку між зарядом і стінкою свердловини.

Практична значимість. Розроблена конструкція заряду дозволяє нейтралізувати шкідливі гази, що утворюються під час вибуху, зменшити пік тиску у ближній до заряду зоні, і може широко використовуватись на нерудних кар'єрах, де ведеться видобуток корисних копалин з метою виробництва щебню.

Ключові слова: забруднення навколищнього середовища, вибух, вибухова речовина, конструкиія заряду, икідливі гази, втрати корисних копалин, нейтралізаџія газів

\section{Ресурсоэффективная и экологически безопасная конструкция заряда для открытых горных работ}

\section{О. Твердая, Е. Кофанова, Н. Репин, А. Кофанов, К. Ткачук, Н. Гуц, Э. Кабана}

Цель. Целью исследования является уменьшение потерь полезных ископаемых и загрязнения окружающей среды вредными газами и пылью во время взрывного разрушения горных пород на нерудных карьерах.

Методика. Для достижения целей исследования применялись методы физико-химического анализа и механики сплошных сред. Метод физико-химического анализа применялся для определения количественных и качественных характеристик состава забойки скважины в зависимости от параметров скважины, типа взрывчатого вещества, количества и типа вредных газов, образуемых во время взрыва. Методы механики сплошных сред использовались для установления закономерностей прохождения волн давления при взрыве в зависимости от характеристик заполнителя промежутка между зарядом и стенкой скважины. Для решения задачи о поведении двухслойной среды в процессе нагружения цилиндрической полости нестационарными нагрузками использовался численный метод на основе конечно-разностной схемы предиктор-корректор Мак-Кормака.

Результаты. Разработана ресурсосберегающая и экологически безопасная конструкция взрывного заряда, предусматривающая создание промежутка между зарядом и стенкой скважины и заполнение его суспензией гидроксида кальция или суспензией карбоната кальция.

Научная новизна. Установлены зависимости объема вредных газов $\left(\mathrm{NO}_{2}, \mathrm{CO}_{2}, \mathrm{CO}\right)$, образующихся при взрывном разрушении горных пород, и величины пика давления в ближней к заряду зоне от химического состава заполнителя радиального промежутка между зарядом и стенкой скважины.

Практическая значимость. Разработанная конструкция заряда позволяет нейтрализовать вредные газы, образующиеся при взрыве, уменьшить пик давления в ближней к заряду зоне, и может быть широко использована на нерудных карьерах, где ведется добыча полезных ископаемых с целью производства щебня.

Ключевые слова: загрязнение окружающей среды, взрыв, взрывчатое вещество, конструкиия заряда, вредные газы, потери полезных ископаемых, нейтрализачия газов 